damaged germination and early growth of all crops, while under the same conditions an equivalent amount of ammonium sulphate was harmless. Alternatives to superphosphate have been tested, but none so far has proved superior to this well-tried substance, a fact, surely, that would have gratified Rothamsted's founders. Work has continued in the Pedology Department on the mineralogy of soil components, the determination of which is of great help to the Soil Survey. Materials from Britain and from abroad have been studied, and a number of unusual minerals identified.

The nitrogen cycle and the ecology of soil micro organisms remain the two major interests of the Soil Microbiology Department. The relationship between Rhizobium trifolii and its phage has been studied, and changes in the latter have been noted during storage in artificial soil. A fungistatic action by certain aerobic spore-forming bacteria has been demonstrated in all soils examined except those with a strong acid reaction, and it is suggested that such bacteria may be responsible for fungistasis in natural soil in the field. Other investigations have concerned the bacterial decomposition of herbicides and cellulose.

Various aspects of plant nutrition and growth have continued to interest the Botany Department, particularly the effect of nutrients on root and leaf growth. The known relation of leaf area to crop yields makes such studies of considerable practical interest. The effects of nitrogen, phosphorus and potassium on leaf area have been examined, as was that of gibberellic acid. The effect of this last was one of increasing the leaf area rather than the photosynthetic activity of the plant. A foliar application of gibberellic acid to potato increased leaf area and crop yield but caused some malformation of the tubers.

Plant enzymes engaged the attention of the Biochemistry Department, and an article on "Bracken Thiaminase" by R. H. Kenten is included in the report. This study has not yet produced results of practical application in bracken eradication, but a useful and necessary start has been made in acquiring the basic knowledge essential to a solution of this most important agricultural problem.

The contribution of Rothamsted to our knowledge of plant viruses is universally appreciated and needs no advertisement. The Plant Pathology Department is as active as ever in this field and much detailed and fundamental research continues. Electron microscopy has added much to our knowledge of viruses, but advances in technique are needed for this tool to be fully exploited. Possibilities in this direction are under continuous examination, and the published work of the Department is proof of the progress made in this very critical matter. In addition to the better-known plant viruses, those of cereals and grasses have received attention. Yellow dwarf virus is increasing in cereal crops in Britain, but more needs to be known concerning its effect on yield. Results recorded here suggest that this is more severe on oats than on wheat and barley. The susceptibility of various grasses to infection by cereal viruses and the identification of their vectors have also been studied.

Work on eelworms of economic importance and their predators has been the concern of the Nematology Department, while the Insecticides and Fungicides Department has continued the study of the pyrethrins and the effect of environmental conditions on the toxicity of various insecticides and fungicides.

The Entomology Department is working on various aspects of the biology and ecology of insect pests, in particular, aphids, frit fly, gall midges and the wheat bulb fly. The study of the behaviour, physiology, nutrition and the diseases of bees has been continued by the staff of the Bee Department.

Statistics have always figured largely in the work of Rothamsted, and the installation of an electronic computer has increased both the range and the volume of the work of the Statistics Department. In addition to work on the Station's own experimental data, help has been given to outside institutions in planning experiments and analysing results.

The report includes a list of the field experiments now in progress on the Rothamsted and Woburn farms and an account of the year's progress in the Soil Survey of England and Wales. Accompanying the article on bracken thiaminase already mentioned are papers by Mary D. Glynne and G. A. Salt on "Eyespot of Wheat and Barley" and by R. G. Warren on "The Residual Effects of the Manuring and Cropping Treatments in the Agdell Rotation Experiment".

The list of contributions to scientific journals made during the year with which the report ends bears evidence of the industry with which current problems are being investigated at Rothamsted and are a tribute to all concerned. J. H. WESTERN

\title{
EAST AFRICAN AGRICULTURE AND FORESTRY RESEARCH ORGANIZATION
}

\author{
REPORT FOR 1957
}

\begin{abstract}
$\mathrm{T}$ HE East African Agriculture and Forestry Research Organization is an inter-territorial research organization administered by, and forming part of, the East Africa High Commission. It is jointly financed by the three East Africa Territories of Kenya, Tanganyika and Uganda, the Protectorate of Zanzibar and the United Kingdom Government through the Colonial Development and Welfare Fund. The principal functions are to undertake long-term research work on behalf of the Territorial Departments
\end{abstract}

of Agriculture and Forestry or to investigate problems which require highly specialized equipment or research officers. The present report (East Africa High Commission: East African Agriculture and Forestry Research Organization. Record of Research for the period Ist July, 1956, to 31st December, 1957. Pp. vii +112 . (Nairobi : Government Printer, 1958.) Sh. 3/50) describes examples of each of these types of work and contains much of interest to all those concerned with agriculture and forestry in the 
tropics. The Physics Division in collaboration with the plant physiologist has continued to investigate the water relationships of plants and soils, and in particular have been concerned with problems associated with the most economical use of available water. This work also involves calculation of the amount of water which crops use from week to week, from simple meteorological and basic soil data. The prediction of crop responses of the soil and the build-up of nitrates in the soil due to decomposition of soil humus are two important aspects of the work of the Chemistry Division. It has now been shown that soil humus may be divided into two parts. One part is held by the soil and is resistant to decomposition even if the soil is kept warm and moist. The other much smaller part is in the soil solution and oxidizes rapidly under these conditions. Humus comes into solution when a dry soil is wetted, and the drier the soil before wetting the greater the amount of organic matter coming into solution. Thus, nitrates are only produced in the soil in appreciable quantities during the first rains after the dry season, and if leaching occurs there is not likely to be appreciable production of new nitrate later on. This emphasizes the need to get crops established as early as possible in the wet season. The Plant Pathology Division, starting with Central American varieties of maize, has successfully completed a breeding programme to give varieties resistant to tropical American maize rust, Puccinia polysora, a disease which first occurred in East Africa in 1952. Forestry investigations are mainly concerned with problems in the drier areas of East Africa. The Animal Nutrition Division has made extensive analyses of the main organic components of several local grasses at different times of the year, and the apparent digestibility of these grasses has been compared with those from temperate regions. Collecting of botanical specimens has actively continued and the services of the herbarium for identification of specimens has been in great demand from neighbouring territories.

\title{
ELECTRON RESONANCE STUDY OF THE RADICALS PRODUCED BY CONTROLLED POTENTIAL ELECTROLYSIS OF AROMATIC SUBSTANCES
}

\author{
By D. E. G. AUSTEN, Dr. P. H. GIVEN, DR. D. J. E. INGRAM and \\ M. E. PEOVER \\ British Coal Utilisation Research Association, Leatherhead, Surrey \\ and \\ Department of Electronics, University of Southampton
}

T HE negative ions formed by electron transfer from sodium metal to hydrocarbon molecules in tetrahydrofuran solution have received much attention in the past year or so, and recently studies have been extended to the similar ions formed in the same way by carbonyl, nitro and cyano derivatives ${ }^{1}$. The same radical-ions have been postulated as the primary products of the polarographic reduction of aromatic hydrocarbons in dioxan-water ${ }^{2}$ and of aromatic carbonyl compounds in the non-proton-active solvent dimethylformamide ${ }^{3}$. These inferences from polarographic behaviour have not hitherto been supported by any direct demonstration that the ions are indeed present. We wish to report such a demonstration, obtained by measuring the electron resonance signal given by solutions electrolysed under the polarographic conditions.

Anthracene, benzophenone and anthraquinone have been electrolysed (the apparatus and method are described in ref. 4) in $0 \cdot 1 \mathrm{~N}$ tetraethylammonium iodide in dimethylformamide, using a stirred mercury cathode the potential of which was maintained at a velue corresponding to the top of the first wave of each substance $\theta^{4,5}$. Under these conditions the polarographic evidence indicates that the paramagnetic mononegative ions should be formed (Fig. 1) :

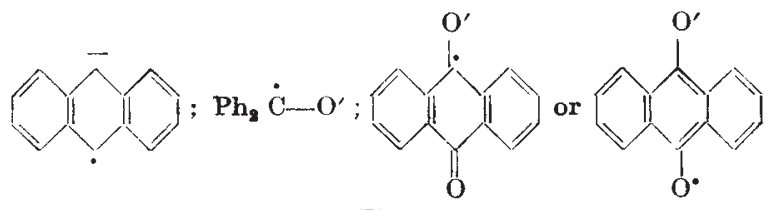

Fig. 1

At intervals during the electrolyses, samples were withdrawn under oxygen-free nitrogen into tubes of a size to fit the resonant cavity exactly. The tubes were immediately chilled in liquid nitrogen and sealed, and the signal was measured, a few hours later, in a 3-cm. wave-length electron resonance spectrometer. This employed an $H_{014}$ rectangular cavity cooled to liquid-oxygen temperatures, and obtained high sensitivity by magnetic field modulation at $100 \mathrm{Kc} / \mathrm{s}$., and phase-sensitive detection ${ }^{6}$. The

Table 1. Details of Reaction Conbitions and ter Products

\begin{tabular}{|c|c|c|c|c|c|c|c|c|}
\hline Substance & $\begin{array}{c}-E_{1 / 2} \text { (volt) } \\
\text { versus } \\
\text { mercury pool }\end{array}$ & $\begin{array}{c}\text { Controlled } \\
\text { potential } \\
\text { (volt) }\end{array}$ & $n^{*}$ & $\begin{array}{c}\text { Concentration } \\
\text { of solution } \\
(\mathrm{m} M)\end{array}$ & $\begin{array}{c}\text { Max. concen- } \\
\text { tration free } \\
\text { radicals (mM) }\end{array}$ & Nature of product & $\begin{array}{c}\text { Lige- } \\
\text { width } \\
\text { (gauss) }\end{array}$ & $\begin{array}{c}g \text {-value } \\
\pm 0.001)\end{array}$ \\
\hline Anthracene & $1 \cdot 41,1 \cdot 88$ & $\begin{array}{l}-1.55 \\
-1.55\end{array}$ & 2 & $\begin{array}{l}40 \cdot 1 \\
28 \cdot 1\end{array}$ & $\begin{array}{l}0.31 \\
0.30\end{array}$ & Dihydroanthracene & 18 & $2 \cdot 005$ \\
\hline $\begin{array}{l}\text { Benzophenone } \\
\text { Anthraquinone }\end{array}$ & $\begin{array}{l}1 \cdot 22,1 \cdot 47 \\
0 \cdot 33,0 \cdot 90\end{array}$ & $\begin{array}{l}-1.3 \\
-0.5\end{array}$ & $\begin{array}{l}2 \\
1\end{array}$ & $\begin{array}{l}33 \cdot 0 \\
12 \cdot 7\end{array}$ & ${ }_{18}^{0 \cdot 83}$ & $\begin{array}{l}\text { Benzhydrol } \\
\text { Equimol. mixture } \\
\text { anthraquinone + } \\
9: 10 \text {-diacetoxy- } \\
\text { anthracenet }\end{array}$ & $\begin{array}{l}19 \\
11\end{array}$ & $2 \cdot \overline{007}$ \\
\hline
\end{tabular}

* $n=$ Faradays of electricity/mole of reducible substance. $\dagger$ Product was acetylated. 